\title{
Antibacterial potency of mangosteen pericarp extracts (Garcinia mangostana $L$.) against Fusobacterium nucleatum
}

\author{
Nia Pramais Octaviani, ${ }^{1}$ Latief Mooduto $^{2}$ and Achmad Sudirman ${ }^{2}$ \\ ${ }^{1}$ Student of Dental Medicine \\ ${ }^{2}$ Teaching Staff of Dental Medicine \\ Faculty of Dental Medicine, Universitas Airlangga \\ Surabaya-Indonesia
}

\begin{abstract}
Background: Fusobacterium nucleatum is a common bacterial in root canal with pulp necrosis and periradicular lesion. A way to eliminate these bacteria from root canal is by root canal irrigation. Root canal irrigation materials that are widely used nowadays has many shortcomings. The pericarp of mangosteen (Garcinia mangostana L) has antibacterial potency. Therefore mangosteen pericarp can be an alternative material which could inhibit and bactericidal function to Fusobacterium nucleatum. Purpose: The aim of this study was to determine the antibacterial potency of mangosteen pericarp extract (Garcinia Mangostana L.) against Fusobacterium nucleatum. Methods: This study was laboratory experimental with pos-test only control group design. A microdilution method was used to determine minimum inhibitory concentration and minimum bactericidal concentration by colony counting bacteriae in Tryptone Soya Agar (TSA) media with drop plate technique. Growth of bacterial colonies in TSA is calculated manually in colony forming unit (CFU/ $\mathrm{ml}$ ). Results: Bacterial colonies growth at concentration $0.78 \%$ was $90 \%$ less than positive control group and there were no bacterial colonies growth at concentration $0.975 \%$. Conclusion: The Minimum Inhibitory Concentration (MIC) of mangosteen pericarp against Fusobacterium nucleatum was at 0,78\% concentration and the Minimum Bactericidal Concentration $(M B C)$ was at $0.975 \%$ concentration.
\end{abstract}

Keyword: pericarp mangosteen extract; Antibacterial potency; Fusobacterium nucleatum

Correspondence: Nia Pramais Octaviani, Student of Dental Medicine, Faculty of Dental Medicine, Universitas Airlangga. Jl. Mayjen. Prof. Dr. Moestopo No.47, Surabaya 60132, Indonesia. Email: niapramais@gmail.com

\section{INTRODUCTION}

Dental and oral health problems are still a problem. Based on the 2007 Riskesdas data, $75 \%$ of Indonesia's population has a history of dental caries with a severity of teeth (DMF-T index) of 5 teeth per person. Caries is a disease whose etiology consists of various factors. Untreated caries can cause bacteria to invade the pulp, resulting in an inflammatory response that will continue to become necrotic. The necrotic pulp easily leads to colonization of microorganisms. ${ }^{1}$

According to study on the identification of microorganisms in root canals with exposed pulp due to caries and periradicular lesions, it was found that the most bacteria in these canals are true anaerobic bacteria. ${ }^{1}$ One of the microorganisms that often cause damage to the pulp is Fusobacterium spp. ${ }^{2}$

Fusobacterium Nucleatum is thought to be one of the bacteria that causes hypersensitivity reactions in teeth, this is due to Fusobacterium nucleatum can produce ammonia.
This vapor from ammonia causes inflammation of the tooth tissue and is able to stimulate bradykinin as a mediator of pain. $^{3}$

Fusobacterium nucleatum is one of the obligate anaerobic gram-negative bacteria found in $5.74 \%$ in deep caries and is ranked second after Prevotella spp. Fusobacterium nucleatum is one of the caries-causing bacteria that can be found in dental plaque, root canals and periodontal infections. ${ }^{4}$

Teeth that have damaged the pulp need root canal treatment, which is dental care by removing all necrotic pulp tissue in the root canal. The basis of root canal treatment is endodontic triad, which consists of preparation and irrigation, sterilization, and obturation. Mechanical preparation of the root canal is an important step in removing necrotic tissue. Mechanical preparation must always be accompanied by irrigation to clean pieces of pulp tissue and dentine fragments. ${ }^{5,6}$

Root canal irrigation materials must have broad spectrum antibacterial power, be able to dissolve remnants 
of pulp tissue that are necrotic, non-toxic to tissue, do not injure periodontal tissue, and do not cause anaphylactic reactions. There are various types of irrigation solutions in root canal treatment, such as sodium hypochlorite $(\mathrm{NaOCl})$, $\mathrm{H}_{2} \mathrm{O}_{2}$, chlorhexidine, citric acid, iodine-potassium-iodide, and EDTA solution. The use of synthetic irrigation materials has several side effects, one of which is cytotoxic caused by $\mathrm{NaOCl}$ when in contact with soft tissue. ${ }^{7.8}$

Utilization of plants as traditional medicine is currently increasing. Plants are materials that are often used because they have the ability to replace synthetic materials. One of the ingredients that potentially has medicine is mangosteen pericarp. Mangosteen pericarp contains several compounds which according to the literature have pharmacological activities such as anti-inflammatory, antihistamine, antibacterial, antifungal, even for HIV therapy. ${ }^{9}$

Phytochemical screening shows that mangosteen pericarp extracts contains saponins, tannins, polyphenols, flavonoids, alkaloids, and xanthones. Saponin is active substances that can increase membrane permeability so resulting cell hemolysis. If saponin interact with bacterial cells, then the bacteria will be damaged or lysis. Flavonoid is a group of phenol compounds that have a tendency to bind to proteins, thus disrupting metabolic processes. Tannins in low concentrations are able to inhibit bacterial growth, while at high concentrations are able to act as antibacterial by coagulating or agglomerating bacterial protoplasms to form stable bonds with bacterial proteins. ${ }^{10}$ Xanthones in mangosteen pericarp have active components that have pharmacological effects such as analgesics, antitumor, antiinflammatory, hypo-allergenic, antifungal, antioxidant, as well as having antibacterial activity that have been tested on S. aureus, E. coli, Shigella dysentriae, and recent studies show effectiveness Antibacterial in Flavobacterium and Enterobacter. ${ }^{11,12,13}$

To date, there has been no study on the antibacterial potency of mangosteen pericarp extracts against Fusobacterium nucleatum which is one of the pathogenic bacteria in the root canal. The purpose of this study was to determine the antibacterial potency of mangosteen pericarp extracts (Garcinia mangostana L.) in inhibiting and killing the bacterium Fusobacterium nucleatum.

\section{MATERIALS AND METHODS}

This type of study was laboratory experimental with post test only control group design. Bacteria used were stock bacteria Fusobacterium nucleatum ATCC 25586. Bacteria were cultured in Tryptone Soya Broth (TSB) media. The turbidity of the bacterial suspension Fusobacterium nucleatum is likened to the 0.5 Standard McFarland.

Mangosteen pericarp powder used in this study came from Balai Materia Medika, Batu, East Java. Dry mangosteen pericarp powder is then macerated. Mangosteen pericarp powder of $1 \mathrm{~kg}$ was inserted into the extractor and $96 \%$ ethanol solvent was added with a ratio of 1: 2 mangosteen pericarp powder. Stirring using a stirrer/shaker for 2 x 24 hours. Then filtering was performed thus a clear red transparent filtrate is obtained. After that, the filtrate was evaporated using a rotary evaporator with a temperature of $60^{\circ} \mathrm{C}$ until all the alcohol was separated and the obtained crude mangosteen pericarp extracts was brown and thick.

Mangosteen pericarp extracts material was taken as much as $100 \mu \mathrm{l}$ each and then put into a microtiter plate with a bacterial suspension that has been prepared in advance of $100 \mu \mathrm{l}$ with a ratio of $1: 1$. Then incubated at $37^{\circ} \mathrm{C}$ for 24 hours. Determination of inhibitory concentration and kill concentration was conducted by counting the number of colonies in each concentration using Drop Plate method. From each tube $50 \mu \mathrm{l}$ was taken, then dropped on TSA media. Then incubated at $37^{\circ} \mathrm{C}$ for 24 hours. The number of bacterial colonies was calculated and expressed in units of colony forming unit (CFU) / $\mathrm{ml}$ liquid (suspension).

After calculating the number of colonies, data processing and analysis was conducted by using SPSS with Kolmogorov-Smirnov test. After that the homogeneity was tested by Levene's Test. Homogeneity data that has been tested then performed nonparametric Kruskal Wallis and Mann Whitney Test . Non-parametric tests were conducted to see the significance of differences in the number of bacterial colonies between study groups.

\section{RESULTS}

Based on the results of study on the antibacterial power of mangosteen pericarp extracts against bacteria Fusobacterium nucleatum obtained data as in the following figure.

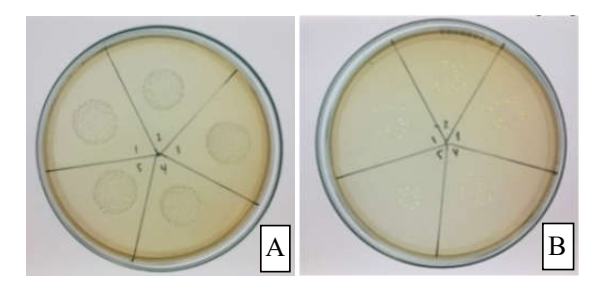

Figure 1. A. Growth in positive controls; B. growth at $0.78 \%$ concentration.

In petri dishes containing mangosteen pericarp extracts with $1.56 \%, 1.365 \%, 1.17 \%$, and $0.975 \%$ concentration there was no growth of colonies Fusobacterium nucleatum. Colony growth was found at $0.78 \%$ mangosteen pericarp extracts concentration and positive control.

Table 1. Study Result Data

\begin{tabular}{lccc}
\hline $\begin{array}{l}\text { Concentration } \\
\text { Group }\end{array}$ & $\mathrm{N}$ & $\begin{array}{c}\text { Average number of } \\
\text { colonies }(\mathrm{CFU} / \mathrm{ml})\end{array}$ & $\begin{array}{c}\text { Average number } \\
\text { of colonies (\%) }\end{array}$ \\
\hline $1.56 \%$ & 5 & 0 & 0 \\
$1.365 \%$ & 5 & 0 & 0 \\
$1.17 \%$ & 5 & 0 & 0 \\
$0.975 \%$ & 5 & 0 & 0 \\
$0.78 \%$ & 5 & $3.04 \times 10^{11}$ & 9.62 \\
Control (+) & 5 & $3.16 \times 10^{12}$ & 100 \\
Control (-) & 5 & 0 & 0 \\
\hline
\end{tabular}


Based on the data obtained KHM at $0.78 \%$ concentration, because the bacterial growth rate of less than $10 \%$ is $9.62 \%$, while at $0.975 \%$ concentration bacterial growth was not found, so that $0.975 \%$ was MBC.

To find out normality in each group test was carried out Kolmogorov Smirnov test. The test results showed that at $0.78 \%$ concentration, $p=0.974(p>0.05)$ and positive controls $p=1,000(p>0.05)$. This shows that the concentration group is normally distributed. Then the homogeneity test was performed with Levene's test and $\mathrm{p}=0.017(\mathrm{p}<0.05)$ which means that the data is not homogeneous. To find out the difference between group Kruskal Wallis test and the results seen in the table below.

Table 2. Test Results Kruskal-Wallis

\begin{tabular}{lc}
\hline Concentration & Significance \\
\hline Concentration $0.975 \%$ & \\
Concentration $0.78 \%$ & 0.002 \\
Positive control & \\
\hline
\end{tabular}

From the table above was obtained the value of $\mathrm{P}=$ $0.002(\mathrm{P}<0.05)$. This shows that there were significant differences in cleanliness of root canal wall $0.975 \%, 0.78 \%$ concentration and positive control. Then to find out which groups are different the test is performed Mann-Whitney. The Test results Mann-Whitney seen in the table below.

Table 3. Test Results Mann-Whitney

\begin{tabular}{lcc}
\hline & $\begin{array}{c}\text { Concentration } \\
0.975 \%\end{array}$ & $\begin{array}{c}\text { Concentration } \\
0.78 \%\end{array}$ \\
\hline Concentration & - & 0.005 \\
$0.975 \%$ & 0.005 & - \\
$\begin{array}{l}\text { Concentration } \\
0.78 \%\end{array}$ & 0.005 & 0.009 \\
Positive Control & & 0 \\
\hline
\end{tabular}

From the non-parametric Mann Whitney U test results showed that the significance between the concentration of $0.975 \%$ and $0.78 \%$ of $0.005(\mathrm{p}<0.05), 0.78 \%$ concentration and positive control of $0.009(\mathrm{p}<0.05)$, and $0.975 \%$ concentration and positive control of $0.005(\mathrm{p}<0.05)$. The size of the Mann Whitney $U$ test was $p<0.05$ which means that there were significant differences between each concentration group.

\section{DISCUSSION}

This study was conducted to determine the antibacterial potency of mangosteen pericarp extracts against Fusobacterium nucleatum. The antibacterial potency of mangosteen pericarp extracts against the bacteria Fusobacterium nucleatum was measured by observing the Minimum Inhibitory Concentration (MIC) and Minimum Bactericidal Concentration (MBC). In this research, the antibacterial sensitivity test used the colony count method with drop plate technique. This is based on the consideration of the mangosteen pericarp extracts that is murky and dark so it is difficult if done by the dilution method. This method is used because it can show quantitative results that show the concentration of antibacterial needed to kill bacteria.

Preliminary study was conducted to find the range of minimum inhibitory concentration (MIC) and minimum bactericidal concentration (MBC) of mangosteen pericarp extracts against the bacterium Fusobacterium nucleatum. Series dilution was carried out (serial dilution) ranging from $100 \%$ to $0.78 \%$. From preliminary study it is known that the MIC and MBC are located between $1.56 \%$ and $0.78 \%$ concentration. Further study is conducted to determine the $\mathrm{MIC}$ and $\mathrm{MBC}$ among these concentrations.

The study result showed that at $1.56 \%, 1.365 \%, 1.17 \%$ and $0.975 \%$ concentration was no found bacterial growth (sterile) in the media, while at $0.78 \%$ concentration the growth of bacterial colonies Fusobacterium nucleatum that could inhibit more than $90 \%$ of bacteria compared with positive control. The amount of mangosteen pericarp extracts used at $1.56 \%, 1.365 \%, 1.17 \%$ and $0.975 \%$ concentration was higher than $0.78 \%$ concentration. The difference in the amount of extracts given also causes a difference in the amount of active substances contained in the mangosteen pericarp extracts. The difference in the amount of active substances contained in pericarp extracts affects the ability of mangosteen pericarp extracts to inhibit the physiological activity of the bacterial cells Fusobacterium nucleatum. Therefore, the number of bacterial cell colonies that died at $0.78 \%$ concentration was less than at $1.56 \%, 1.365 \%, 1.17 \%$ and $0.975 \%$ concentration. Based on the results of the study showed the antibacterial potency of mangosteen pericarp extracts against the growth of bacteria is Fusobacterium nucleatum directly proportional to the increased concentration of mangosteen pericarp extracts. This is relevant with the theory that the higher the concentration of mangosteen pericarp extract, the greater the damage to bacterial cells. Damage caused by the antibacterial ingredients of mangosteen pericarp extracts cannot be followed by repair of the bacterial cells themselves, so the bacteria will lysis and the number of colonies is reduced. ${ }^{14}$ From these results, the concentration of $0.78 \%$ is the Minimum Inhibitory Concentration (MIC) and the concentration of $0.975 \%$ is the Minimum Bactericidal Concentration (MBC) of mangosteen pericarp extracts against Fusobacterium nucleatum.

The mechanism of mangosteen pericarp extracts in inhibiting and killing inhibit Fusobacterium nucleatum is related to the activity of active components of mangosteen pericarp extracts which works to cell DNA synthesis, energy metabolism, and permeability function of the plasma membrane. Flavonoids inhibit the action of restriction endonuclease enzymes, so that transcription does not occur in RNA and this results in bacterial cell division not due to protein system disruption. ${ }^{15}$ Flavonoids also cause changes in cell membrane permeability and interfere with cell metabolism by inhibiting the electron transport chain. 
The antibacterial activity of xanthones and saponins is not much different from flavonoids, which form complex compounds against extracellular proteins that interfere with cell membrane integrity. The antibacterial agent of the other active ingredient of mangosteen pericarp extracts, namely tannins penetrate into cells and react with bacterial membrane proteins. Tannin bonds with cell membranes cause damage to the cytoplasmic membrane which can ultimately inhibit and kill the bacteria Fusobacterium nucleatum. From the results of the study it can be concluded that the extract of mangosteen pericarp (Garcinia mangostana L.) has an antibacterial power against Fusobacterium nucleatum which can inhibit bacterial growth at $0.78 \%$ concentration and kill at $0.975 \%$ concentration.

\section{REFERENCES}

1. Torabinejad, M., Walton R.E. Endodontics Priniples and Practice. $4^{\text {th }}$ ed. St. Louis: Saunders Elsevier; 2009. p. 40-2

2. Putri, Srianna Rostyarini. Daya Hambat Mikroorganisme Menggunakan Larutan Tetrasiklin HCL 5\%, 10\%, dan 15\% Sebagai Bahan Irigasi pada Perawatan Saluran Akar. Thesis: Universitas Airlangga; 2005.

3. Hahn CL, Falkler WA Jr. Correlation between thermal sensitivity and microorganisms isolated from deep caries. J. Encoded 1993; 19: 26 - 30.

4. Maripandi A, Kumar AT, and Salamah A. Prevalence of Dental Caries Bacterial Pathogens and Evaluation of Inhibitory Concentration Effect on Different Tooth Paste Against Streptococcus spp. African Journal of Microbiology Study. 2011; p: 1780
5. Grossman LI, Oliet S, Delrio CE. Ilmu Endodontik dalam Praktik, alih bahasa: Rafiah Abyono, 11 ${ }^{\text {th }}$ ed. Jakarta. 1995. p: 250-1, 279-80

6. Shahani MN, Reddy VVS. Comparison of antimicrobial substantivity of root canal irrigants in instrumented root canals up to $72 \mathrm{~h}$ : an in vitro study. J Indian Soc Pedod Prev Dentistry. 2011; P:29

7. Kandaswamy D, Venkateshbabu N. Root canal irrigants. Journal of Conservative Dentistry 2010; 13:256-64

8. Flavio R. F. et al. Antibiofilm and Antibacterial Activities of Farnesol and Xylitol as Potential Endodontic Irrigants. Brazilian Dental Journal. 2013; 24(3). p:228

9. Chaverri, Pedrazza. J. et al. Medicinal properties of mangosteen (Garcinia mangostana).Food Chem. Toxicol.,2008; 46, p: 3227-39.

10. Poeloengan., dan Praptiwi. Uji Efektivitas Ekstrak Kulit Buah Manggis (Garcinia mangostana Linn). 2010; p: 68

11. Jung HA, Su B, Keller WJ, Mehta RG, Kinghorn AD. Antioxidant Xanthones from the Pericarps of Garcinia mangostana (Mangosteen). Journal of Agricultural Food Chemical 2006; 54. p:2077-82

12. Chitra S, Krithika MV, Pavithra, S. Induction of Apoptosis by Xanthones from Garcinia Mangostana in Human Breast and Laryngeal Carcinoma Cell Lines. International Journal of Pharma and Bio Sciences 2010; 1(3). p:8

13. Maliana, Y., S. Khotimah., dan F. Diba, Aktivitas Antibakteri Kulit Garcinia mangostana Linn. terhadap Pertumbuhan Flavobacterium dan Enterobactercoptotermes curvinathus Holmgren. Jurnal Protobiont, 2013; 2 (1) : 7-11

14. Bagg, J., Mac Farlane, T. W., Poxton, I. R., Smith, A. J., Essentials of Microbiology for Dental Students, 2nd ed, Oxford University Press, Glasgow, 2006; pp. 115-116

15. Cushnie TP \& Lamb J. Review antimicrobial activity of flavonoids. IJAA 2005; 26. p: 343, 350-1 